\title{
Teoritisasi Komunikasi Dalam Tradisi Sosiokultural
}

\author{
Eko Nugroho \\ D III Hubungan Masyarakat, Fakultas Ilmu Sosial, Universitas Negeri Jakarta \\ Email: ekonugroho37@gmail.com \\ Diterima 16 November 2019 / Disetujui 24 Desember 2019
}

\begin{abstract}
The Last Samurai is a Hollywood production film made by Edward Zwick (2003) which won 4 (four) Oscars for several categories at the 2004 Academy Award. In this film, we can see Katsumoto and Algreen at first debating or disagreeing about ways the customs. Socioculturally, there are keywords that can be seen in the film's story, namely "culture" and "interaction". First, that there are different cultural settings from the two figures. They think in terms of two different structural meanings. Sociocultural theories provide explanations in many communication contexts. In general, this tradition explains the following ideas (Littlejhon and Foss, 2005: 45). First, our way of understanding, meaning, norms, roles and rules work interactively in communication. Sociocultural traditions authorize communication in a concept of "reproduction of social order". In this case the interaction as a discussion of communication events becomes an activity that involves the symbols that are based on the meaning, interpretation. And in interaction there is also a convention, an agreement based on the division of meaning of symbols between community members that determines the internal factors (self-concept, or identity, etc.) of each group member, so that the order or rules change as the actuality of the communication itself .
\end{abstract}

Keywords: Sociocultural; Social Order; The Last Samurai

\begin{abstract}
ABSTRAK
The Last Samurai adalah film produksi Hollywood yang dibuat oleh Edward Zwick (2003) yang memenangkan 4 (empat) Oscar untuk beberapa kategori di Academy Award 2004. Dalam film ini, kita bisa melihat Katsumoto dan Algreen pada awalnya berdebat atau tidak setuju tentang cara-cara bea cukai. Secara sosial budaya, ada kata kunci yang bisa dilihat dalam cerita film, yaitu "budaya" dan "interaksi". Pertama, bahwa ada pengaturan budaya yang berbeda dari dua tokoh. Mereka berpikir dalam dua arti struktural yang berbeda. Teori sosiokultural memberikan penjelasan dalam banyak konteks komunikasi. Secara umum, tradisi ini menjelaskan ide-ide berikut (Littlejhon dan Foss, 2005: 45). Pertama, cara pemahaman, makna, norma, peran, dan aturan kami bekerja secara interaktif dalam komunikasi. Tradisi sosiokultural mengesahkan komunikasi dalam konsep "reproduksi tatanan sosial". Dalam hal ini interaksi sebagai diskusi tentang peristiwa komunikasi menjadi kegiatan yang melibatkan simbol-simbol yang didasarkan pada makna, interpretasi. Dan dalam interaksi ada juga konvensi, kesepakatan berdasarkan pembagian makna simbol antara anggota masyarakat yang menentukan faktor internal (konsep diri, atau identitas, dll) dari masing-masing anggota kelompok, sehingga urutan atau aturan berubah sebagai aktualitas dari komunikasi itu sendiri.
\end{abstract}

Kata kunci: Sosiokultural; Tatanan sosial; The Last Samurai 


\section{PENDAHULUAN}

The Last Samurai adalah sebuah film produksi Hollywood besutan Edward Zwick (2003) yang berhasil meraih 4 (empat) piala Oscar untuk beberapa kategori pada Academy Award tahun 2004. Film ini dibintangi oleh Tom Cruise dan Ken Watanabe. Film tersebut berlatar kondisi Jepang di era awal restorasi Meiji. Tokoh utama dalam film tersebut adalah Nathan Algreen (Tom Cruise), seorang veteran tentara "yankees" Amerika dan seorang penasihat kaisar yang juga seorang Samurai Lord Katsumoto (Ken Watanabe). Film ini mengisahkan Algreen yang bemigrasi ke Jepang karena suatu kontrak kerja dengan seorang saudara Jepang Mr. Omura. Ia dikontrak sebagai seorang prajurit bayaran yang ditugasi sebagai instruktur dalam memodernisasi angkatan perang Jepang kala itu. Dalam beberapa adegan, ada beberapa percakapan menarik. Suatu kala Algreen tertangkap dan dia menyaksikan seorang koleganya berkebangsaan Jepang dalam keadaan bersimpuh melakukan suatu ritual robek perut (Seppuku) dan berakhir dengan pemenggalan kepala. Dalam keadaan setengah sadar, Algreen dibawa ke desa para Samurai. Sebuah desa yang dilingkupi oleh adat istiadat dan aturan-aturan kelas feodal Jepang era ke-shogun-an. Suatu lingkungan yang berbeda dengan lingkungan barat (Amerika) kala itu. Lingkungan dengan disiplin dan tata kehidupan yang sama sekali berbeda. Dimana kebiasaan kebiasaan "aneh" yang tidak ditemui Algreen di Amerika banyak menganggu pikirannya. Termasuk kebiasaan para Samurai yang memaknai berbagai hal tentang keprajuritan, berbeda dengan kelas prajurit di Amerika dan dunia barat kala itu. Misalnya, kenapa Samurai masih menggunakan pedang, bahkan tetap begitu dalam menghadapi angkatan perang yang menggunakan senapan. Dalam logika militer sederhana ala barat, ini adalah sebuah ketololan yang tragis.

Singkat cerita, Algreen bercakap cakap dengan Katsumoto. Suatu kala, Algreen diminta menemui Katsumoto. Ia memasuki bangsal sebuah kuil dengan berjalan seenaknya. Dan kemudian mereka mengawali percakapan mereka. Tanpa meperkenalkan diri, Algreen memulai pembicaraan lalu Katsumoto mengingatkan bahwa tidak sopan berbicara tanpa memperkenalkan diri dulu, bahkan kepada musuh. Ini adalah salah satu adat samurai.

Dalam percakapan lain, mereka berbeda pendapat tentang makna "membunuh" dan "kematian". Algreen menganggap cara-cara Seppuku sebagai cara yang tidak patut. Membunuh musuh yang sudah menyerah adalah sebuah kepengecutan menurut Algreen. Namun Katsumoto sebagai seorang samurai menganggap itu adalah hal yang terhormat. 
Bahwa seorang samurai yang sudah kalah, dia lebih memilih Seppuku ketimbang menanggung malu. Seppuku berbeda dengan bunuh diri biasa, Seppuku lebih ke "ritual" keprajuritan dan seperti pengampunan dosa, yang mana seorang samurai tetap dihormati sebagai pahlawan meskipun kalah. Intinya kalau dia melakukan Seppuku ini merupakan hal terhormat, sementara Algreen menganggap itu adalah tindakan yang kejam.

Kematian bagi Algreen dengan pengalaman budayanya --sebagai anak buah jenderal Custer yang dalam sejarah perang negara Paman SAM dianggap sebagai "pahlawan bermasalah", karena tindakannya menghabisi sejumlah besar suku Indian itu --- memiliki nilai horror dan tragis. Kematian kemudian bagi Algreen adalah tragedi sedangkan bagi Katsumoto dan keluarganya kematian adalah kehormatan.

Dalam film ini, bisa kita lihat Katsumoto dan Algreen pada awalnya berdebat atau berbeda pendapat tentang cara-cara adat istiadat. Misalnya perlakuan terhadap musuh. Dimana menyebutkan nama dalam duel ataupun kondisi tertentu itu adalah keharusan bagi seorang samurai, sementara bagi seorang Amerika seperti Algreen, itu adalah sebuah basa basi. Kemudian pandangn tentang Seppuku, Algreen menganggap itu suatu kepengecutan. Bahwa bunuh diri adalah suatu ketololan kultural dalam budaya barat. Budaya barat memandang bunuh diri sebagai sebuah tabu. Sementara bagi kerangka budaya samurai, bunuh diri adalah sebuah kehormatan.

Tapi, akhirnya dengan sebuah interaksi yang dalam, mereka kemudian saling memahami dan mengenal budaya mereka, yang pada akhirnya kohesi di antara mereka menjadi penyelesaian cerita dari film ini. Dimana akhirnya Algreen menerima budaya samurai dan menjadi seorang yang memegang budaya samurai sebagai identitas barunya, sampai akhirnya dia mejadi seorang pelaku Seppuku. Dalam hal ini, Algreen sebagai orang yang mendampingi atau pengeksekusi buat Katsumoto yang menyimbolkan penerimaan budaya bagi Algreen.

Apa yang menyebabkan Algreen dan Katsumoto berbeda dalam adat istiadat keprajuritan sementara mereka sama-sama "student of war"--- meminjam perkataan Katsumoto----? Kenapa Katsumoto dan Algreen memaknai kematian dengan cara yang berbeda? Lalu apa yang menyebabkan kemudian mereka memiliki pemahaman yang bersinggungan dan memperkuat kohesi mereka, sehingga Algreen pada akhirnya bisa menerima budaya samurai dan menjadikan kerangka budaya samurai sebagai idetitas baru bagi Algreen? 
Secara sosiokultural, ada kata kunci yang terlihat pada cerita film ini yaitu “ budaya" dan "interaksi “. Pertama, bahwa ada latar budaya yang berbeda dari dua tokoh tadi. Mereka berfikir dengan dua kerangka struktur pemaknaan yang berbeda. Mereka mencoba untuk saling memperkenalkan diri bahkan saling mempengaruhi satu sama lain. Kedua, interaksi antar dua orang beda budaya ini akhirnya membuat Algreen menerima budaya Samurai dan begitupun kemakluman Katsumoto pada Algreen hingga mereka memiliki sebuah pemahaman yang bersinggungan.

Disini terlihat adanya suatu reproduksi tatanan sosial. Dimana perbedaan kerangka budaya mempengaruhi suatu pemaknaan yang berbeda dan berujung pada perbedaan interpretasi tentang sesuatu. Lalu interaksi merubah perbedaan itu dan tentu saja ini melalui suatu proses komunikasi yang intensif. Dari cerita film ini, bisa diambil sebuah hikmah bahwa komunikasi merupakan suatu kegiatan memaknai dan membangun interaksi. Melaluinya suatu reproduksi terhadap tatanan sosial terjadi. Ini berujung pada bagaimana seseorang memaknai lingkungan komunikasinya, memaknai orang lain dan memaknai diri sendiri. Ini semua lagi-lagi ada peran budaya dalam membangun peristiwa komunikasi. Dan komunikasi di lain pihak bisa menjadi sebuah awal dari terbentuknya konvensi tertentu mengenai suatu budaya atau masyarakat.

Peristiwa komunikasi esensinya adalah sebuah aktivitas manusia yang bukan hanya sebuah tindakan individual, tetapi ini menyangkut sebuah perilaku yang terikat erat dengan keberadaannya dalam masyarakat, kelompok, bangsa atau organisasi. Craig dan Muller berpendapat bahwa masyarakat sangatlah tidak mungkin ada tanpa sebuah peristiwa komunikasi yang mengawalinya. Dan di lain sisi, menurutnya komunikasi juga tidak bisa dilakukan tanpa adanya pola tindakan dan makna (masyarakat dan budaya) (Craig dan Muller, 2007 ).

Ada hubungan saling ketergantungan antara komunikasi manusia dengan budaya. Bahwa komunikasi memang merupakan kegiatan atau suatu perilaku yang intinya adalah pertukaran informasi, namun makna yang dialokasikan oleh individu dari informasi yang diterimanya adalah sesuatu yang dipengaruhi bukan hanya situasi, tetapi oleh suatu pertukaran yang ada sebelumnya (Fortman dan Giles dalam Baldwin et all (ed), 2006 : 94). Pertukaran informasi dan cara-cara yang ada sebelumnya telah terkristalisasi dan terpola dalam struktur pengalaman yang berada dalam bentuk budaya dan bentuk social order tertentu. Sehingga, komunikasi pada dasarnya adalah tergantung pada latar belakang 
sosiokultural (struktur sosial tertentu) dan di satu sisi, komunikasi juga menentukan bagaimana orang memaknai atau berkomunikasi di masa depan. Ini adalah sebuah reproduksi sosial yang terus berjalan antara struktur sosial yang membangun pemaknaan seseorang dan tindakan komunikasi yang mampu membangun sebuah pemahaman baru tentang struktur itu dan mendialektisirnya secara sosial.

Paper ini ingin menjelaskan bagaimana komunikasi diteoritisasikan sebagai sebuah reproduksi tatanan sosial, dan bagaimana aspek-aspek teoritik dari tradisi atau paradigma sosiokultural ini menjelaskan komunikasi melalui asumsinya maupun varian teorinya.

\section{Asumsi-asumsi dan Karakteristik}

Teori-teori sosiokultural memberikan penjelasan dalam banyak konteks komunikasi. Secara umum, tradisi ini menjelaskan ide-ide berikut (Littlejhon dan Foss, 2005 : 45). Pertama, cara pemahaman kita, makna, norma, peran dan aturan bekerja secara interaktif dalam komunikasi.

Kedua, tradisi ini menjelaskan dunia interaksional, dimana, orang hidup menempatkan ide bahwa realitas bukanlah perangkat objektif dari sebuah aturan di luar kita akan tetapi ini sebuah konstruksi yang dibentuk melalui proses interaksi dalam grup, komunitas dan budaya.

Ketiga, menjelaskan lebih kepada pola interaksi daripada karakterisik indivual ataupun mental models. Dalam hal ini, kata kuncinya interaksi dalam skala mikro, maka yang dibahas bukan model mental tetapi proses interaksi yang dibangun dalam internal individu untuk diagregasi menjadi sebuah interaksi yang lebih besar. Secara makro, proses interaksi itu sendiri membentuk konsepsi besar seperti budaya, makna, dan masyarakat.

Keempat, tradisi ini sangat tertarik untuk membahas komunikasi dalam actual use. Dimana tradisi ini melihat fenomena atau empiri komunikasi dalam kejadian-kejadian pada situasi aktual. Misalnya tradisi ini membedakan antara pikiran dan bahasa, dimana pikiran adalah proses internal yang membangun suatu endapan dari masa lalu dan memanggil atau melogikakan serta mengkategorisasi endapan tersebut, lalu timbullah kategori simbolis. Sedangkan bahasa adalah simbol-simbol dengan perangkat aturannya yang digunakan dalam interaksi aktual. Masa lalu hanya endapan yang kemudian dipotong potong untuk dibahasakan. Jadi masa lalu tidak memiliki pengaruh terhadap konstruksi bahasa atau 
bahasa tidak dipengaruhi oleh masa lalu (actual) tetapi dipengaruhi oleh aktifitas pikiran tentang masa lalu. Ini merupakan konsep present thinking (Charon, 2007).

\section{METODE PENELITIAN}

Metode penelitian yang digunakan ialah metode penelitian kualitatif sebagai suatu pendekatan atau penelusuran untuk mengeksplorasi dan memahami suatu gejala sentral. Data didapatkan dari film berjudul The Last Samurai, yang kemudia dianalisis oleh penulis.

\section{HASIL DAN PEMBAHASAN}

Setiap preposisi teori tentu bekerja pada asumsi tertentu. Asumsi dalam tradisi sosiokultural berkisar di antara beberapa hal, yakni pertama, realitas manusia secara umum dibentuk oleh bahasa yang di acu budayanya sejak kecil, asumsi ini dibangun berdasarkan beberapa asumsi teoritis, salah satunya dari hipotesis Sapir dan Whorf. Ini adalah premis yang terkenal yang mendasari asumi teori-teori dalam tradisi. Terkait penggunaan bahasa, Sapir dan Whorf berpendapat bahwa struktur bahasa membentuk apa yang orang pikirkan (Penn, 1972 : 13-32). Bahasa secara umum adalah bagian dari budaya, sehingga konstruksi kebahasaan adalah konstruksi budaya yang diujungnya adalah membentuk realitas dari individu.

Kedua, realitas dalam komunikasi dibentuk oleh sesuatu proses yang di luar/ mendahului realitas itu sendiri. Bahwa realitas memiliki pola tertentu yang ada sebelum peristiwa komunikasi ataupun relitasnya terjadi, sehingga pola komunikasi (budaya, social order dan lain-lain) dibentuk lebih dulu oleh kehidupan sebelumnya ---dengan kata lain, realitas dikonstruksikan atau menjadi sebuah konstruksi realitas------ , atau realitas kita di konstruksi oleh kehidupan sebelumnya dan kita mengkonstruksikan juga kehidupan yang akan datang (Berger dan Luckman, 1979 ).

Ketiga, manusia adalah makhluk sosial, melalui interaksi masyarakat terbentuk, sehingga implikasi dari asumsi ini yaitu bahwa komunikasi adalah interaksi dan ditentukan oleh interaksi manusia, sehingga komunikasi menentukan realitas manusia dan masyarakat (Charon, 2007 ).

Keempat, manusia adalah makhluk yang berpikir (Charon, 2007), bahwa tindakan sosial manusia bukan hanya lahiriah atau dipengaruhi oleh interaksi eksternal tetapi juga interaksi internal dari manusia. Interaksi ini terjadi dalam proses berpikir dimana 
manusia menghadapi interaksi antar komponen-komponen psikologi dan aspek spiritualnya. Dalam pandangan psikoanalisa ada dialektika antara ide, ego dan super ego (Freud, 1960). Dalam terminologi interaksionik simbolik, ditemukan konsep self, I, me dan lain-lain yang saling berinteraksi (Griffin, 2012 ).

Kelima, manusia mendefinisikan lingkungan dimana mereka berada (Charon, 2007), bahwa pandangan manusia tentang lingkungannya adalah hasil dari definisinya melalui sebuah interaksi panjang. Ia pada dasarnya tidak melihat lingkungan sebagaimana adanya lingkungan itu sendiri, akan tetapi melalui sebuah definisi tentang lingkungan. Seorang anak kecil bisa melihat sebuah bandara sebagai tempat bermain yang luas dalam definisinya yang mempertimbangkan derajat interaksi yang masih sangat minim. Sedangkan seorang jenderal militer, melihat bandara sebagai tempat atau titik akses ancaman.

Keenam, penyebab dari tindakan manusia adalah hasil dari apa yang terlihat/ terjadi dalam situasi kita sekarang (Charon, 2007). Seseorang berbuat kejahatan bukan karena masa lalunya, tetapi karena dia berpikir tentang masa lalunya. Proses berpikir, interaksi, definisi situasi yang terjadi saat ini. Sedangkan masa lalu masuk ke dalam kehidupan dan tindakan kita karena kita memikirkannya dan menyatukannya dalam definisi.

Ketujuh, manusia dianggap sebagai makhluk yang aktif terhadap hubungannya dengan lingkungan (Charon, 2007). Manusia bukanlah makhluk pasif tapi dia hidup dengan kemampuan memanipulasi ataupun mengkontrol lingkungan. Kita mengkontrol apa yang kita lakukan, bukan sebaliknya kita dikontrol oleh sesuatu (lingkungan) untuk melakukan sesuatu.

Dari asumsi di atas, sebenarnya tradisi ini seperti yang diungkapkan Craig dan Muller berbeda dengan tradisi sosiopsikologi misalnya, yang memiliki keseragaman atau mayoritas seragam dalam hal asumsi dan bentuk preposisi. Menurut mereka, ada dua sisi pandang tentang komunikasi dan budaya serta social order dalam paradigma sosiokultur (Craig dan Muller, 2007). Pertama, komunikasi merupakan fenomena yang ditentukan atau dipenuhi oleh suatu aturan tertentu, di mana makna-makna dibangun berdasarkan suatu struktur tertentu. Ini sejalan dengan pandangan-pandangan makro dari strukturalisme yang melihat secara umum adanya sebuah struktur yang mempengaruhi kerja, tindakan dan sistem pemaknaan manusia. 
Kedua, manusia secara aktif memproduksi atau menentukan aturan-aturan yang berlaku dalam sistem sosial. Dimana secara mikro manusia berfikir dan kemudian berkomunikasi untuk menentukan suatu hukum umum, aturan (rule), peran melalui interaksi yang esensinya komunikasi untuk membangun sebuah pola yang akan diturunkan atau diaplikasikan di antara mereka sebagai konvensi, kode, simbol, identitas dan bahkan konsep diri.

Sehingga, komunikasi diteorisasikan sebagai "reproduction of social order", dimana komunikasi adalah fenomena yang bergantung pada struktur social order. Dan di sisi lain, dia adalah juga sebuah usaha atau aktivitas manusia menentukan aturan-aturan melalui berbagai prosesnya untuk membangun sebuah tataran atau meruntuhkan sebuah tatanan dan membangun kembali social order yang baru untuk generasi berikutnya.

Asumsi di atas bukanlah asumsi yang memiliki satu implikasi tetapi paling tidak ada dua implikasi yang berbeda, yang nantinya akan membangun sebuah variasi pada teori di tradisi ini. Pertama, aspek mikro sosial, dimana asumsi bekerja pada individu dan yang kedua, aspek makro sosial, asumsi bekerja pada masyarakat, bangsa dan entitas besar budaya.(Craig dan Muller, 2007) Sehingga, sosiokultural adalah tradisi yang menteoritisasikan komunikasi dalam konteks fenomena mikro atau individu, dan konteks fenomena makro atau fenomena masyarakat, kelompok, dan bangsa serta budaya.

Ketika bicara sosiokultural, maka dalam banyak teorinya mengetengahkan termaterma umum yang terkait asumsi ini. Pertama, terma bahasa, dimana komunikasi diteorisasikan sebagai peristiwa kebahasaan, dimana sentral hubungan proses komunikasi dari para aktor adalah dualisme bahasa. Bahasa sendiri kemudian menjadi struktur (social order). Di sisi lain, bahasa juga adalah alat untuk membangun struktur itu sendiri (creating social order). Ini sejalan dengan dualisme struktur Giddens ---dalam kajian teori kritis ---yang menggambarkan dinamika agen dan struktur yang saling mengatur, meniadakan dan membentuk dalam dinamika tertentu (Giddens, 1986). Ini mengimplikasikan bahasa sebagai entitas utama dalam perubahan sosial dalam pembangunan struktur dan alat aktor dengan statusquonya memanifestasikan----- (dan mendialektisir dalam terma kritika)----praktik-praktik atau tindakan sosialnya. Melalui skema kebahasaan (interpretive scheme), terjadi reproduksi social order, dimana structure menghidupkan aturannya melalui modalitas tertentu dan begitupun agen yang berinteraksi dalam modalitas skema interpretive--- melalui sistem bahasa. Sehingga dualisme struktur sendiri adalah bisa 
dipertimbangkan menteorisasikan komunikasi sebagai reproduksi social order (Giddens, 1986).

Kedua, culture atau budaya, teori dan model berbasis teori interaksionik simbiolik atau beberapa teori lainnya, menjadikan ini sebagai terma sentral yang menggambarkan dinamika sosial komunikasi manusia. Dimana komunikasi diteoritisasikan sebagai peristiwa budaya. Terma ini menurut Keesing (1974) merupakan "teori" tentang "permainan yang sedang dimainkan" dalam masyarakat kita. Menurut Gudykunst dan Kim, budaya memberitahu kita bagaimana untuk berkomunikasi dengan orang lain dan bagaimana menginterpretasi perilaku mereka, dimana dalam budaya terkait komunikasi secara umum terdapat sebuah persetujuan umum pada aturan-aturan tertentu (Gudykunst dan Kim, 1997).

Ketiga, simbol-simbol, merupakan semua hal yang digunakan untuk merepresentasikan hal lain, dan disetujui penggunaannya oleh kelompok orang tertentu dalam penggunaan yang umum (Gudykunst dan Kim, 1997). Dalam hal ini, terma komunikasi diteoritisasikan sebagai sebuah aktivitas simbolik yang mana melibatkan penggunaan simbol dan usaha-usaha interpretasi terhadapnya dalam interaksi antar manusia.

Keempat, society, masyarakat dalam tradisi ini secara umum dipandang sebagai sebuah konfigurasi interaksi simbolis (Blumer, 1986). Masyarakat lebih kepada sekelompok besar orang yang saling berinteraksi dengan menggunakan simbol-simbol. Sebagai suatu komunitas interpretif, dimana dalamnya pertukaran simbol dan pemaknaan serta reproduksi sosial terjadi.

Kelima, terma identitas, komunikasi diteoritisasikan sebagai sebuah refleksi atau pengaruh dari identitas, atau komunikasi merupakan pembentuk identitas itu sendiri. Menurut Yep, identitas adalah sebuah konsepsi seseorang tentang dirinya dalam sebuah konteks sosial, geografism, kultural dan politik tertentu, identitas memberikan kepada individu suatu rasa dari diri dan kepribadian (Samovar et al, 2007 ).

Terma-terma lain bisa jadi muncul lebih banyak seiring perkembangan tradisi dan teori-teori sociocultural. Hanya saja, yang ingin ditunjukan disini adalah setiap terma memandang komunikasi dalam lingkup konseptualnya sendiri sehingga komunikasi dalam tradisi ini memiliki teoritisasi yang berbeda-beda namun berujung pada akar yang sama bahwa adanya reproduksi social order. 


\section{Varian Teori dalam Tradisi Sosiokultural}

Studi teori komunikasi dalam paradigma sosiokultural memiliki sejumlah varian dengan beberapa karakteristik tertentu. Ini didasarkan pada lingkup objek kajian dan beberapa asumsi yang menunjukkan adanya perbedaan pendekatan pada hubungan komunikasi dengan aturan sosial budaya, serta pembagian unit analisa dan objek dari fenomena komunikasi yang coba dijelaskan.

Craig sendiri menjelaskan bahwa tradisi sosiokultural terbagi dalam dua pembagian besar, makro sosial dan mikro sosial. Teori-teori makrososial adalah teori-teori terkait melihat komunikasi dalam gambaran titik pijak masyarakat sebagai satu keseluruhan, sedangkan mikro sosial melihat komunikasi dalam konteks pemahaman individual dan group (Craig dan Muller 2007).

Contoh teori-teori makro adalah teori group think, teori ini dikemukakan oleh Irving Janis (Littlejhon, Foss dan Oetzel, 2017). Teori ini secara umum memiliki bidang kajian pada kelompok. Teori ini secara umum memaparkan sebuah hipotesis bahwa tingkat kohesivitas yang tinggi antar anggota group dari sebuah kelompok dalam kondisi tertentu akan mengarah pada penurunan tingkat berpikir kritis, dan lemahnya pengambilan keputusan. Teori ini berskala makro, dalam hal ini berkisar di antara gejala dalam kelompok sosial tertentu.

Contoh teori mikro adalah teori interaksionik simbolik yang kajiannya menyangkut pembentukan konsep-konsep diri dari manusia dalam interaksinya melihat bagaimana interaksi dibangun dari hal mikro, yaitu struktur kejiwaan manusia dan bagaimana struktur kejiwaan itu dibangun oleh interaksi itu sendiri.

Littlejhon dan Foss menggambarkan setidaknya ada beberapa variasi dari tradisi sosiokultural ini (Littlejhon dan Foss, 2005). Pertama, interaksionik simbolik, teori-teori dari varian ini dikenal luas memiliki variasi konsep dan terkadang asumsi-asumsi atau implikasi yang cukup variatif. Salah satu yang terkenal dari varian teori ini adalah interaksionik simbolik versi Herbert Mead. Menurut Mead, komunikasi hanya akan terjadi jika ada sebuah hubungan antar individu sebelumnya. Dimana dari hubungan ini, ada semacam aturan atau penilaian yang menjadi acuan komunikasi bagi individu. Seseorang tidak bisa berkomunikasi jika tidak ada kepentingan yang sama dan tidak ada aktifitas yang kooperatif antara pihak yang berkomunikasi. Bahwa masyarakat hanya akan terbentuk jika 
adanya partisipasi dalam komunikasi antar individu. Tanpa keterikatan yang dibangun dari dalam diri terhadap para pihak, maka tidak akan ada komunikasi (Mead, 1934). Asumsi yang dibangun Mead di sini adalah komunikasi (interaksi) yaitu sebuah syarat penting bagi masyarakat. Dan sebuah komunikasi akan terjadi dengan baik jika orang memiliki sebuah kerangka dan aturan yang sama tentang banyak hal dan masyarakat hanya akan terjadi jika ada suatu bentuk komunikasi yang baik. Dimana adanya kesamaan kepentingan dan aktifitas yang kooperatif. Hampir semua teori-teori interaksionik simbolik mengasumsikan komunikasi sebagai bentuk interaksi yang diawali dengan sebuah pemahaman awal (aturan awal) dalam diri seseorang dan kemudian mereka membentuk pemahaman bersama dalam suatu "society".

Blumer mengatakan bahwa, manusia selalu mencoba untuk menginterpretasikan tindakan orang lain. Dimana ini adalah basis dari interaksi manusia. Interaksi manusia sendiri merupakan mediasi oleh simbol dan dengan mengoperasikan proses interpretasi makna yang terbentuk, dan inilah yang menentukan tindakan tindakannya atau definisinya terhadap keadaan dan tindakan manusia lain (Blumer, 1986). Dari pendapat Blumer ini, komunikasi diteoritisasikan sebagai kegiatan atau aktifitas interpretasi simbol dan pertukaran simbol antara individu dalam interaksi sosial.

Kedua, konstruksionisme, teori-teori ini adalah teori yang memiliki pijakan dari filsafat konstruksionisme. Teori ini mengasumsikan realitas kita adalah sebuah realitas yang dikonstruksikan sebelumnya. Dan kita dalam upaya juga membangun realitas tertentu untuk masa depan. Varian ini dapat merujuk pada contoh teori konstruksi relitas sosial yang dikonsepsikan oleh Berger dan Luckman (1979). Komunikasi diteoritisasikan sebagai proses mengkonstruksi relitas itu sendiri. Dimana komunikasi didalamnya menggunakan simbol-simbol yang berasal dari sistem simbol (sebagian besar bahasa). Sistem simbol adalah konstruksi relitas, melalui fase-fase utama yang dikemukakan oleh Berger dan Luckman, yaitu obyektifikasi, institusionalisasi, dan legitimasi (Berger dan Luckman, 1979). Sehingga, komunikasi diteoritisasikan sebagai suatu aktifitas dimana dialektika antar konstruksi realitas struktural dan usaha-usaha manusia dalam mengkonstruksi relitas.

Ketiga, sosiolinguistik, Wittgenstein berpendapat bahwa makna dari sebuah kata adalah penggunaannya pada bahasa. Penggunaan bahasa yang dimaksud oleh Wittgenstein adalah penggunaannya sekarang atau present use (Adler dalam Stalmaszczyk, 2014) komunikasi dalam hal ini dipandang oleh teori-teori sosiolingustik terikat pada konteks, 
dimana makna berubah seiring waktu dan ruang dan juga tergantung konteks penggunaannya. Komunikasi diteoritisasikan sebagai sebuah produksi makna yang terikat konteks, dimana konteks ruang waktu bisa mereproduksi makna dari sebuah simbol yang menyebabkan berubahnya makna seiring waktu. Dan actual use dari sebuah simbol atau komunikasi pada saat sekarang berbeda dengan komunikasi pada masa lalu.

Makna yang dibentuk pada saat sekarang dalam komunikasi, tidak bisa secara pasti menyasar apa yang dimaksudkan seperti ketika kata atau pesan itu dulu digunakan. Wittgenstein mengatakan "what can be shown, cannot be said" (Silverman dan Torode 1980 : 430) bahwa sistem linguistik manusia sangat terbatas untuk menggambarkan realitas. Komunikasi diteoritasikan sebagai sumberdaya yang terbatas untuk menggambarkan atau menciptakan pemaknaan yang berujung pada terbatasnya pembacaan realitas. Ini disebabkan social order yang dibangun oleh bahasa adalah terbatas untuk menggambarkan realitas. Sehingga, bahasa membangun social ordernya sendiri ketimbang menggambarkan realitas itu sebagai refleksi pada social order. Sosiolinguistik berkenaan dengan penggunaan bahasa bukan sebagai gramatika, tetapi sebagai fungsi sosialnya, yaitu fungsi komunikasinya yang mencoba membangun suatu diskursi tentang realitas.

Satu lagi yang merupakan tambahan dari variasinya adalah etnografi dan ethno metodologi, ethnometodologi menurut Garfinkel merupakan suatu upaya melihat --menteoritisasikan-kehidupan sehari hari atau tata cara kehidupan sehari hari dalam konteks sosiologis, dimana tata cara tersebut menurutnya adalah sebuah aturan untuk bertindak --- menurut tata cara tersebut--- dan bagaimana anggota kelompok membangun tata cara kehidupan tersebut (Garfinkel, 1967). Tata cara tersebut bisa juga merupakan aturan untuk berinteraksi. Dengan ini, tentu ethno metodologi bisa dilihat sebagai teori untuk menjelaskan komunikasi sebagai tata cara atau sebagian dari tata cara kehidupan praktis manusia sehari hari di mana melaluinya tata cara tersebut dipraktekkan dan bahkan dibuat. Dan tentu saja komunikasi dijelaskan dalam sebuah kerangka "pembuat atau proses pembuatan tata cara tersebut" atau komunikasi sebagai tata cara kehdupan sehari hari tersebut.

Terakhir Ethnografi, ethnografi hampir sama dengan ethno metodologi yaitu sebuah metode yang berdimensi teoritis, artinya sebuah teori yang menjadi metode sekaligus. Troike dalam bukunya The Ethnography of Communication (2003) mengatakan bahwa fokus dari etnografi (dalam hal ini konsep etnografi komunikasi) adalah komunitas bahasa (speech community). Dalam komunitas ini menurut teori komunikasi terpola dan 247 I Com municology Vol. 7 ( no) 2 Tahun 2019 
terorganisasi sebagai sistem dari pengalaman komunikasi (Troike, 2003) bahwa bahasa atau komunikasi itu sendiri adalah sebuah peristiwa atau fenomena yang tersirat secara kultural atau dipengaruhi oleh budaya. Bahasa merupakan bentuk budaya yang terkondisikan secara sosial yang artinya tercipta dari interaksi sosial --yang tentu saja ini membentuk budaya itu sendiri. Makna yang terbentuk adalah hasil dari komunikasi itu sendiri dalam narasi budaya pada suatu komunitas.

Yang membedakan etnografi dengan etno metodologi adalah bahwa titik tekan teori ethnografi adalah pada bagaimana kemudian makna dibentuk atau esensi budaya membentuk pengertian-pengertian tentang sesuatu dalam komunitas. Sedangkan ethnometodologi menitik beratkan pada kajian atau pembedahan tata cara atau aturanaturan yang dibentuk oleh komunikasi, baik mengenai cara hidup, cara pandang maupun cara berkomunikasi. Tata cara disini adalah cara berkomunikasi dalam konteks komunitas.

\section{Definisi Komunikasi dan Beberapa Catatan Implikatif dari Tradisi Sosiokultural}

Tradisi sosiokultural dengan varian teori dan ragam pandangan dan asumsinya menghasilkan banyak definisi komunikasi. Komunikasi dihubungkan dengan konteks budaya dan interaksi manusia secara umum. Dimana komunikasi adalah interaksi simbolik bukan sebuah proses transmisi. Komunikasi menurut Carey paling tidak memiliki dua pandangan utama yang menurunkan definisi-definisi. Pandangan transmisi dan pandangan ritual (Carey, 2009 ). Pandang transmisi menjelaskan komunikasi sebagai proses transmisi pesan dari komunikator ke komunikan, sedangkan pandangan ritual komunikasi merupakan interaksi dan interpretasi menggunakan simbol dan berbagi makna antar anggota dalam komunitas, masyarakat dan budaya. Komunikasi digambarkan sebagai aktifitas "shared belief'.

Tradisi sociocultural secara teoritis telah memberlakukan komunikasi dalam pandangan ritual ketimbang pandangan transmisi. Ini melihat karakteristik utama dari tradisi ini. Littlejhon dan Foss (Littlejohn dan Foss, 2005) mengatakan bahwa tradisi sosiokultural ini melihat beberapa hal yaitu yang pertama, adanya penciptaan realitas oleh kelompok sosial di mana proses informasi dipengaruhi oleh komunikasi yang tercipta secara sosial, atau interaksi sosial mempengaruhi relasi dari seseorang dalam suatu masyarakat atau kelompok. 
Kedua, teori-teori di tradisi ini cenderung tertarik pada bagaimana makna dibuat dalam interaksi sosial. Penekanannya jelas pada pembagian atau berbagi makna antara anggota masyarakat dan kelompok. Ketiga, identitas yang dibangun melalui interaksi, sekali lagi interaksi disini dimaknai secara ritual yaitu anggota kelompok berbagai makna tentang sesuatu dan dengan interaksi dalam sebuah komunitas maka terbentuk identitas dalam individu anggota komunitas.

Keempat, komunikasi terbentuk oleh konteks tertentu, pada tradisi ini konsep konteks komunikasi dibeberkan dalam sebuah penjelasan eksplisit menjadi bagian dari premis-premis ataupun asumsi-asumsi yang diajukan. Kelima, penekanan pada simbol, ada makna yang berbeda dari simbol seiring perubahan konteks dari individu dalam masyarakat. Seiring dengan pergerakannya dari tempat satu ke tempat lain ataupun perubahan waktu, maka makna dari simbol berbeda. Dimana simbol bermakna dalam kerangka acuan yang aktual.

Dari asumsi-asumsi yang dikemukan, implikasi yang dihasilkan dari paradigma ini adalah sebuah definisi tentang komunikasi. Berkenan dengan ini perlu diketahui ada ratusan definisi komunikasi yang menggunakan atau berbasis pada paradigma sociocultural ini. Dan setiap definis masing masing memiliki acuan. Acuan ini bisa dilihat dalam karakteristik definisi komunikasi seperti yang dijelaskan oleh Gudykunst dan Kim (1997) di bawah ini. Ikhtisar definisi ini pada dasarnya tidak memberikan definisi secara umum, tetapi ini adalah aspek dari definisi itu sendiri yang bersandar pada asumsi-asumsi sosiokultural. Pertama, komunikasi adalah aktifitas simbolik. Dari hal ini, bisa dikatakan komunikasi didefinisikan sebagai sebuah peristiwa simbolik. Ini menyangkut pembentukan simbol dan interpretasinya. Aktifitas simbolik hakikatnya adalah reproduksi dari struktur makna, yang mana ini beranalogi dengan "social order". Kedua, komunikasi bukan hanya sebuah proses yang menyangkut transmisi pesan, akan tetapi juga interpretasi pesan. Dari sini, proses komunikasi secara keseluruhan adalah secara fungsional mengirimkan pesanpesan, namun secara struktural ini adalah sebuah proses yang bekerja untuk menginterpretasi pesan-pesan yang merupakan simbol-simbol.

Ketiga, komunikasi melibatkan kreasi makna. Bahwa komunikasi sendiri adalah kegiatan memaknai, dimana makna menjadi sebuah entitas yang dipertukarkan dan dibentuk dalam setiap peristiwa komunikasi. Keempat, komunikasi berlangsung dalam tingkat kesadaraan yang berbeda. Banyak tindakan komunikasi kita dilakukan secara tidak 
sadar karena sudah terbiasa, sehingga komunikasi memiliki bentuk-bentuk dan derajatderajat dalam konteks perbedaan kesadaran dalam berkomunikasi. Di mana kualitasnya menjadi berbeda antar yang bersifat sengaja dengan kesadaran tinggi ataupun yang bersifat tidak disadari.

Kelima, komunikasi membuat prediksi pada out come. Manusia selalu membangun suatu prediksi tentang orang lain dalam komunikasinya. Budaya kita memberikan pola-pola produktif tentang perilaku. Sehingga, kita menempatkan orang atau orang memposisikan kita dalam peristiwa komunikasi berbasis budaya yang diacunya. Keenam, niat atau intense bukanlah suatu kondisi yang harus ada dalam komunikasi. Komunikasi bisa berlangsung tanpa niat tertentu. Aturan simbolis kadang membuat kita diinterpretasikan menurut konfigurasi simbol dan budaya tertentu. Tanpa kita pernah sadar bahwa kita sedang dimaknai menurut tataran makna yang bukan dari tingkat kesadaran atau kesengajaan yang kita tentukan. Ketujuh, setiap pesan komunikasi memiliki dimensi konteks dan dimensi hubungan. Dimensi konteks itu adalah apa yang dikatakannya, dimensi hubungan menyangkut bagaimana itu dikatakan. Sehingga ada pesan-pesan yang terpengaruh budaya tertentu ada juga hubungan-hubungan komunikasi yang dibentuknya dalam level-level tertentu. Ke-delapan, komunikator menerapkan sebuah struktur dalam interaksi mereka, dimana setiap berkomunikasi kita memiliki atau menggunakan aturan komunikasi tertentu yang mana kita menerapkannya juga buat orang lain. Dengan kata lain, struktur makna kita, kita coba terapkan buat orang lain dengan membaginya dalam interaksi.

Asumsi Gudykunst dan Kim ini adalah sebuah sari dari banyaknya definisi komunikasi terutama yang berfokus pada struktur budaya dan interaksi manusia yang menjadi faktor titik tekan utama dari tradisi sociocultural ini.

Tradisi sosiokultural menteoritisasikan komunikasi dalam sebuah kerangka yang berbasis pada interaksi manusia dan budaya, dimana secara umum dalam interaksi segala reproduksi struktur atau social order terjadi. Dari sini komunikasi tidak lagi linier tetapi sirkuler. Komunikasi keluar dari kekangan model model effect yang hanya melihat komunikasi sebagai proses layaknya mesin. Komunikasi bisa dillihat sebgai sebuah ruang perdebatan, ataupun rumah ibadat. Di dalamnya ada pertarungan makna bagi ruang perdebatan, dan sekaligus berbagai makna dalam sebuah metaphor peribadatan. Yang artinya, ini bukan lagi tentang effect tetapi ini tentang makna, konflik dan "toleransi". 
Perbedaan budaya, perbedaan struktur akan membawa manusia sadar tentang posisinya ,tentang identitasnya di satu sisi dia mengerti dengan adanya empati dan rasa berbagi, namun di sisi lain, manusia akan memaksakan struktur pemaknaannya, identitasnya, ataupun “diri”nya pada orang lain. Sehingga, mereka berusaha melakukan generalisasi cultural pada konteks dan lingkungan komunikasinya.

Komunikasi berkenaan juga dengan konflik karena identitas dan struktur yang terbentuk dari interaksi sejatinya adalah dialektika budaya. Sehingga, interaksi di dalam diri, dalam kelompok, atau antara kelompok, atau antar budaya bukan hanya menghasilkan toleransi tetapi sebuah perdebatan konflik identitas, konflik konsep diri. Akibat adanya perbedaan pemaknaan antar lingkar-lingkar budaya dalam komunitas atau dengan komunitas yang berbeda. Sehingga tradisi ini tidak kerap selalu membahas konformitas tetapi juga potensi konflik dan logika konflik berbasis budaya.

Bila ditanya bagaimana komunikasi yang ideal? Karena tidak ada kanun baku yang jelas tentang komunikasi ideal sebagaimana tradisi retorika. Yang ada adalah pergerakan makna, dibentuk atau dihancurkannya sebuah aturan, relativitas bahasa, dan isu-isu yang menggambarkan pluralisme dalam peristiwa komunikasi itu sendiri bahwa komunikasi ditentukan oleh konteksnya yang beragam, oleh tingkat kesadarannya, oleh aktualitasnya, dan oleh kualitas simbolisnya yang semuanya adalah eksplanasi nominal ketimbang rasio yang kemudian meletakkan komunikasi pada rasa budaya dan toleransi ketimbang mekanisme keefektifan yang menerapkan sesuatu tanpa membiarkan interaksi terjadi dengan alami.

\section{PENUTUP}

\section{Kesimpulan}

Tradisi sociocultural menteoritisasikan komunikasi dalam sebuah konsep "reproduksi tatanan sosial". Dalam hal ini interaksi sebagai pembahasan peristiwa komunikasi menjadi sebuah aktifitas yang melibatkan simbol-simbol yang dilatari oleh peristiwa pemaknaan, interpretasi. Dan dalam interaksi ada juga sebuah konvensi, sebuah kesepakatan berdasarkan pembagian makna simbol-simbol antar anggota komunitas yang mendeterminasikan faktor internal (konsep diri, ataupun identitas dan lain-lain) dari setiap anggota kelompok, sehingga tatanan atau aturan berubah seiring aktualitas dari komunikasi itu sendiri. 
Realitas adalah sebuah reproduksi dari hubungan-hubungan struktural dalam setiap aturan dan peran-peran dalam masyarakat. Realitas dibentuk melalui proses konstruksi yang sejatinya adalah reproduksi tatanan sosial itu sendiri melalui interaksi manusia.

\section{DAFTAR PUSTAKA}

Adler, Joachim. (2014). Mapping the Ancient City: Historical Linguistics and Conceptual Clarification dalam Stalmaszczyk, Piotr (ed) (2014) Philosophy of Language and Linguistics; The Legacy of Frege, Rusell, and Wittgenstein, Berlin, De Gruyter

Berger, Peter, L, dan Luckmann, T. (1979). The Social Construction of Reality; A Treatise In The Sociology of Knowledge, Middlesex, Penguin Books.

Blumer, H. (1986). Symbolic Interactionism; Prespective and Methode, Los Angeles, University of California Press.

Carey, J. W. (2009). Communication as Culture; Essays on Media and Society, New York, Routledge.

Charon J.M .(2007). Symbolic Interactionism; an Introduction, an Interpretation, an Integration $9^{\text {th }}$ Edition, New Jersey, Pearson Prentice Hall.

Craig, R. T dan Muller, H. L. (2007). Theorizing Communication Readings Across Traditions, Los Angeles, Sage Publication.

Fortman, J dan Giles, H. (2006). Communicating Culture, dalam, Baldwin, J.R, Faulkner S. L, Hecht M. L, dan Lindsley, S, L (ed), Redefining Culture Perspectives Across the Disciplines, New Jersey, Lawrence Erlbaum.

Freud, S. (1960). The Ego and The Id, London, WW Norton \& Company.

Garfinkel, Harold. (1967). Studies in Ethnomethodology, New Jersey, Prantice Hall.

Giddens, A,. (1979). Central Problems in Social Theory; Action, Structure, and Contradiction in Social Analysis, Berkeley, University of California Press.

Griffin, E. M. (2012). A First Look at Communication Theory 8th Edition, New York, McGrawHill.

Gudykunst, W. B dan Kim, Y. Y. (1997). Communicating with Strangers; an Approach to Intercultural Communication $3^{\text {rd }}$ Edition, Boston, McGrawhill.

Keesing, R. (1974). Theories of Culture, Annual Review of Antropology, vol. 3, 73 - 97.

Littlejohn, S. W, dan Foss, K. A. (2005). Theories of Human Communication 8th, Belmount, Thomson Wodsworth.

Littlejohn, S. W, Foss, K. A, dan Oetzel, J. G. (2017). Theories of Human Communication $11^{\text {th }}$ Edition, Illinois, Waveland Press Inc.

Mead, G. H. (1934). Mind, Self, and Society; from The Standpoint of A Social Behaviorist, Chicago, The University of Chicago Press. 
Penn, Julia. M. (1972). Linguistic Relativity Versus Innate Ideas; The Origins of The Sapir- Whorf Hypothesis in German Thought, Paris, Mouton.

Samovar, L. A, Porter,R. E, dan McDaniel E. R. (2007). Communication Between Culture $\sigma^{\text {th }}$ Edition, Australia, Thomson Wadsworth.

Silverman ,D dan Torode, B. (1980). The material word; some theoriesof language and its limits. London ,routledge \& kegan.

Troike, Muriel Saville. (2003). Ethnography of Communication, an Introduction 3rd Edition, Oxford, Blackwell. 